\title{
Trade Related Aspects of Intellectual Property Rights and Developing countries
}

\author{
Mirësi Çela, PhD Candidate \\ "A. Xhuvani" University, Faculty of Economy, \\ Department of Business - Administration, Albania \\ celamiresi@gmail.com
}

\section{Doi:10.5901/ajis.2014.v3n2p279}

\begin{abstract}
The Trade Related Aspects of Intellectual property rights protection (TRIPS) Agreement, signed in 1994 as a founding element of the WTO, represents the most important attempt to establish a global harmonization of Intellectual Property protection. The purpose of this paper is to give an overview of the international aspects of IPRs, with particular reference to the effects of the TRIPS Agreement, which has been described as "the most significant international undertaking on IPR in history". This paper is mainly descriptive in character. It only attempts to give some aspects of TRIPS and effects in developing countries and which are some of the conventions that protect intellectual property (IP) in the trade system. TRIPS Agreement has three main components, which relate to standards of protection, enforcement and dispute settlement. It does not establish a universal IPR system, instead, it lays down a set of minimum standards for the legal protection of IP that WTO members are expected to comply with. Is TRIPS pro trade? Who will benefit and who will lose from its implementation? These are questions that arise from scholars of developed and developing countries. Finally some conclusions from developing countries perspective derive from the analysis.
\end{abstract}

Keywords: Intellectual property, trade, TRIPS Agreement, developing countries

\section{Introduction}

The TRIPS Agreement is a comprehensive multilateral agreement on intellectual property. It came into being as a result of the negotiations of the Uruguay Round (1986-1994), which represented the final round of General Agreement on Trade and Tariffs (GATT). The GATT negotiations began 1948 were designed to provide rules for international trade in goods, and to reform the international trading system that had arisen in the aftermath of the war. The Uruguay Round signaled an end to the provisional organization and agreement of GATT by creating the World Trade Organization (WTO) on 1 January 1995. The WTO's stated objective (WTO, 2002) is to help trade flow "smoothly, freely, fairly, predictably". Some of the ways it attempts to achieve these aims include (WTO, 2002) administering international trade agreements, acting as a forum for trade negotiations, settling trade disputes, and reviewing national trade policies. The TRIPS agreement was deservedly been described (Maskus, 2000) as "the most significant international undertaking on IPR in history".

This paper is mainly descriptive in character. It attempts to give some aspects of TRIPS and effects in developing countries, and which are some of the conventions that protect IP in the trade system. Also are discussed some of the economic and costs of TRIPS, which is the role of it in access to medicines, and the role of different actors in the international intellectual property regime.

At the end some key messages derive from the analysis of TRIPS agreement effects, cost and benefits from the developing countries perspective.

\section{Intellectual Property Rights Protection and Related International Agreements}

During years (decades) in history, different legal instruments for protecting intellectual property have emerged. These instruments differ in their subject matter, extent of protection, and field of application, reflecting society's objective to balance the interests of creators and consumers for different types of intellectual works. Table 1 provides an overview of the different Intellectual Property Rights (IPRs) instruments.

IPRs are created by national laws and therefore apply at the level of each jurisdiction, independent of such rights granted elsewhere. Accordingly, nations must reach accommodation as their residents seek protection for their intellectual works abroad. Numerous international treaties to promote cooperation among states in the protection of intellectual property have been negotiated over the last 100 years. These treaties are administered by the World 
Intellectual Property Organization (WIPO is a specialized agency of the United Nations). They typically require their signatories to follow national treatment in the protection of IPRs (equal treatment of nationals and non-nationals) and facilitate the registration of intellectual property titles in foreign jurisdictions.

Table 1: IPRs: Instruments, Subject Matter, Fields of Application, and Related International Agreements

\begin{tabular}{|c|c|c|c|c|}
\hline $\begin{array}{l}\text { Types of } \\
\text { intellectual } \\
\text { property }\end{array}$ & $\begin{array}{l}\text { Instruments of } \\
\text { protection }\end{array}$ & $\begin{array}{l}\text { Protected subject } \\
\text { matter }\end{array}$ & $\begin{array}{l}\text { Primary Fields of } \\
\text { Application }\end{array}$ & $\begin{array}{c}\text { Major } \\
\text { International Agreements }\end{array}$ \\
\hline \multirow[t]{4}{*}{$\begin{array}{l}\text { Industrial } \\
\text { property }\end{array}$} & $\begin{array}{l}\text { Patents } \\
\text { Utility models }\end{array}$ & & $\begin{array}{l}\text { Manufacturing } \\
\text { Agriculture }\end{array}$ & $\begin{array}{l}\text { Paris Convention (1883), Patent Cooperation } \\
\text { Treaty (1970), Budapest Treaty (1977) } \\
\text { Strasbourg Agreement (1971) } \\
\text { TRIPS (1996) }\end{array}$ \\
\hline & Industrial designs & $\begin{array}{l}\text { Ornamental designs } \\
\text { of products }\end{array}$ & $\begin{array}{l}\text { Automobiles, apparel, } \\
\text { electronics, etc. }\end{array}$ & $\begin{array}{l}\text { Hague Agreement (1925) } \\
\text { Locarno Agreement (1979) } \\
\text { TRIPS }\end{array}$ \\
\hline & Trademarks & $\begin{array}{l}\text { Identifying signs and } \\
\text { symbols }\end{array}$ & All industries & \begin{tabular}{|l} 
Madrid Agreement (1891) \\
Nice Agreement (1957) \\
Vienna Agreement (1973)
\end{tabular} \\
\hline & $\begin{array}{l}\text { Geographical } \\
\text { indications }\end{array}$ & $\begin{array}{l}\text { Identifying place } \\
\text { names }\end{array}$ & $\begin{array}{l}\text { Agricultural products, } \\
\text { foodstuffs, etc. }\end{array}$ & Lisbon Agreement (1958) . TRIPS \\
\hline $\begin{array}{l}\text { Literary and } \\
\text { artistic property }\end{array}$ & $\begin{array}{l}\text { Copyrights and } \\
\text { neighboring rights }\end{array}$ & $\begin{array}{l}\text { Original works of } \\
\text { authorship }\end{array}$ & \begin{tabular}{|l} 
Printing, entertainment \\
(audio, video, motion \\
pictures), software, \\
broadcasting
\end{tabular} & $\begin{array}{l}\text { Berne Convention (1886), } \\
\text { Rome Convention (1961), Geneva Convention } \\
\text { (1971), Brussels Convention (1974), WIPO } \\
\text { Copyright Treaty (1996), WIPO Performances and } \\
\text { Phonograms Treaty (1996), Universal Copyright } \\
\text { Convention (1952), TRIPS }\end{array}$ \\
\hline $\begin{array}{l}\text { Sui generis } \\
\text { protection }\end{array}$ & \begin{tabular}{|l|} 
Plant breeders' \\
rights \\
Integrated circuits
\end{tabular} & \begin{tabular}{|l|} 
New, stable \\
homogenous, \\
distinguishable plant \\
varieties \\
Original layout \\
designs of \\
semiconductors \\
\end{tabular} & \begin{tabular}{|l} 
Agriculture and food \\
industry \\
Microelectronics \\
industry
\end{tabular} & $\begin{array}{l}\text { Convention of new Varieties of Plants (UPOV, } \\
\text { 1961), TRIPS } \\
\text { Washington Treaty (1989), TRIPS }\end{array}$ \\
\hline Trade secrets & & \begin{tabular}{|l|} 
Secret business \\
information
\end{tabular} & All industries & TRIPS \\
\hline
\end{tabular}

Source: Carsten Fink, 2004.

\subsection{The relationship between TRIPS Agreement and the pre-existing international conventions that it refers to.}

The TRIPS Agreement says WTO member countries must comply with the substantive obligations of the main conventions of WIPO - the Paris Convention on industrial property, and the Berne Convention on copyright (in their most recent versions).

With the exception of the provisions of the Berne Convention on moral rights, all the substantive provisions of these conventions are incorporated by reference. They therefore become obligations for WTO member countries under the TRIPS Agreement - they have to apply these main provisions, and apply them to the individuals and companies of all other WTO members.

The TRIPS Agreement also introduces additional obligations in areas which were not addressed in these conventions, or were thought not to be sufficiently addressed in them.

The TRIPS Agreement is therefore sometimes described as a "Berne and Paris-plus" Agreement.

\subsection{The WTO accession Process}

At multilateral level, developed countries took advantage of the WTO accession process to link trade opportunities to TRIPS implementation by developing countries and to their general performance in IP protection. 
To accede to the WTO, applicant countries are required to conduct a series of informal bilateral negotiations that determine the terms of their final accession agreement. It is required full implementation of TRIPS obligations as a condition to entry into the WTO without transition.

Some of the toughest IP negotiations took place in the case of China, which had been preceded by over a decade of bilateral pressures from the United States, the European Union, and Japan on IP standards and enforcement. (Deere, 2009)

\subsection{What does TRIPS require WTO Members to do?}

TRIPS obliges all WTO members to implement minimum standards of protection within specified deadlines for all categories of intellectual property.

TRIPS puts new and unparalleled emphasis on making privately held IP rights enforceable, demanding stronger provisions in national IP laws to promote enforcement of IP rights at the border and within the domestic market.

In addition, TRIPS incorporates provisions of many earlier WIPO and bilateral agreements, extending them to a broader group of countries and linking them for the first time to an effective enforcement mechanism.

The most part of developed countries already had TRIPS standards and IP institutions; they only had to make minor revisions to domestic IP laws to implement TRIPS

For developing countries this requires them to raise their IP standards, which involves a set of reforms in existing laws or the adoption of new laws ad new administrative guidelines. They need to strengthen or reorganize IP administration and to increase the financial resources allocated to IP issues. (Deere, 2009, p.10)

\subsection{Objectives of TRIPS Agreement}

It is not clear what impact the TRIPS Agreement will have on developing countries and whether it actually meets it objective in the,

'...promotion of technological innovation and to the transfer and dissemination of technology...' (Art 7. TRIPS Agreement, 1994, p.323).

These two factors actually constitute the entire objective of the TRIPS Agreement, as stated in Art 7 of the Agreement entitled "Objectives"

"The protection and enforcement of intellectual property rights should contribute to the promotion of technological innovation and to the transfer and dissemination of technology, to the mutual advantage of producers and users of technological knowledge and in a manner conducive to social and economic welfare, and to a balance of rights and obligations."

\subsection{The three main features of the Agreement are:}

Standards; The agreement sets out the minimum standards of protection to be provided by each Member. Each of the main elements of protection is defined, namely the subject- matter to be protected, the rights to be conferred and permissible exceptions to those rights, and the minimum duration of protection.

The TRIPS Agreement is sometimes referred to as a Berne and Paris- plus Agreement.

Enforcement; The second main set of provisions deals with domestic procedures and remedies for the enforcement of intellectual property rights.

Dispute settlement; The agreement makes disputes between WTO Members about the respect of the TRIPS obligations subject to the WTO's dispute settlement procedures.

The obligations under the agreement will apply equally to all Member countries, but developing countries will have a longer period to phase them in. Special transition arrangements operate in the situation where a developing country does not presently provide product patent protection in the area of pharmaceuticals.

\section{Developed and Developing Countries Perspectives}

"Developed countries, which host the world's largest intellectual property-producing industries, were the key advocates 
for comprehensive minimum standards of protection and enforcement of IPRs. By contrast, many developing countries, which see themselves mostly as a consumer of intellectual property, felt that stronger standards of protection would serve to limit access to new technologies and products, thereby undermining poor countries' development prospects. Not surprisingly, the TRIPS Agreement remains one of the most controversial agreements of the WTO."(Fink, 2004)

It is said that the international architecture of TRIPS Agreement is constructed as one size fits all arrangement. This has caused many discussions as TRIPS imposes uniform standards on all member countries. The difference is that the most enthusiastic supporters of TRIPS, which are developed member countries, during the course of their economic development were slow and hesitant in accepting the uniform intellectual property standards imposed from externally. This helped them in gaining economic benefit compared to others. So they protected most the IP of their citizens and were not so worried for the protection of IP of foreign citizens (Dixon \& Greenhalgh, 2002).

One important conclusion that emerges from the history of institutional development is that it took the developed countries a long time to develop institutions in their earlier days of development. These institutions typically took decades, and sometimes generations, to develop.

This is like to kick the ladder that helped them to climb higher, so when certain level is reached, they impose to the undeveloped or developing countries to respect the rules. (Chang, 2003)

As noted by Maskus, (cited in Dixon \& Greenhalgh, 2002), because TRIPS confers much stronger rights on the developers of intellectual property, the short to medium term impact of TRIPS will be to effect a change in the distribution of gains from intellectual property away from intellectual property users and towards the developers of protected information and intellectual property. This benefits information creators in both the developed and developing world, but as noted above, this will massively favor the developed world.

In their article Archibugi and Filippetti, (2010) raise some thesis in assessing the TRIPS Agreement:

1. TRIPS aims to impose the western IP regime to the rest of the world. The IPRs regime has become stronger in the western world. This trend began in the United States where the scope of IPRs has been extended to additional areas (e.g. software) and additional subjects (public research centers and universities), the other western countries have imitated the same trend. Through TRIPS it is spread the western logic to all countries.

2. TRIPS is the outcome of nondemocratic process driven by a club of US corporations. TRIPS has not been debated and negotiated as a global public good. On the contrary it has been strongly pushed by US. In particular it the outcome of the pressures made by a handful of US corporations which have successfully asked their government to act on their behalf.

3. TRIPS may serve the interests of western corporations but not necessarily of western economies. There is no evidence that TRIPS has been advantageous for American citizens at large. On the contrary, it seems that TRIPS has been important to allow Trans - National Corporations (TNCS) to expand their innovative activities globally, relying on stronger IP regimes abroad.

4. TRIPS alone will not lead to an increase in the technology gap between western countries and emerging countries. Both supporters and detractors of TRIPS have put too much emphasis on the economic significance of legal devices regulating intellectual property. By themselves, legal devices can neither impede developing countries from catching up nor allow developed countries to preserve their dominion in technological innovation. It is much more important to concentrate on the economic rather than the legal conditions that allow or impede countries from maintaining or acquiring their knowledge base. ( Archibugi \& Filippetti, 2010, p.146)

\subsection{Economic benefits and costs of TRIPS}

The signing of TRIPS has generated much controversy about its economic implications for developing countries.

Arguments pro and against the Agreement are as follows;

- Stronger IPRs will stimulate creative industries in developing countries and promote foreign direct investment, with an overall positive development outcome. According to Rapp and Rozek (1990) (as cited by Matthews, 2003) who in their study about correlation between a country's economic development and its level of patent protection, identified benefits for developing countries that were prepared to introduce higher standards of IP protection. The degree to which the TRIPS Agreement can be expected to encourage Foreign Direct Investments (FDI) and technology transfer is likely to vary significantly not only between developing countries, but also between sectors, between economic activities and between product types.

- Fink (2004) discusses the link between FDls and IPRs; he suggests that the mere strengthening of an 
intellectual property regime is unlikely to result in a dramatic increase in inflows of foreign investment. At the same time, past reform experiences suggest that stronger IPRs can positively impact on domestic enterprise development and foreign investment, if they are complemented by improvements in other aspects of the investment climate.

- Opponents of TRIPS have claimed that the Agreement will forestall developing countries' access to new technologies, lead to higher prices and rent transfers from poor to rich countries, and impose high implementation costs in resource-constrained environments.

- As the market share of newly protected products and technologies increases over time, prices above marginal production costs and associated rent transfer are a cause for concern-especially in the case of pharmaceutical products.

- As for the implementation of the Agreement, some argue that TRIPS poses significant institutional and financial challenges for developing countries. For many resource constrained governments in poor countries, implementation costs of a large magnitude would likely impose a significant burden on public sector budgets and draw away resources available for other development priorities.

\section{The Global Politics of TRIPS}

During the years the impact of civil society on the intellectual property standard-setting process, has increased. Nongovernmental organizations (NGOs) after states and business, have become a third force in the global politics of IPRs. According to Drahos (n.d, p. 3) NGOs function as an analytical resource for developing states and as possible partners in a global coalition of minority factions on intellectual property standard-setting issues.

\subsection{IP in the NGOs}

Intellectual Property is not as simple as one legal notion, defined by WIPO and WTO, or by right holders. Nor is IP only trade related. The present discussions show that it is also education- related, health related, nutrition -related, defenserelated, environment -related, and energy-related and so on. Many multilateral organizations have an important interest in the way rights granted are used with respect to inventions within the scope of their regulatory mission. It is therefore not remarkable that these organizations have sought to play a more significant role in the implementation of TRIPS and in the formulation of new rules.

IP is now at or near the top of the agenda in intergovernmental organizations, such as the World Health Organization (WHO), and Food and Agriculture Organization (FAO) (Kur \& Levin, 2011 p.23)

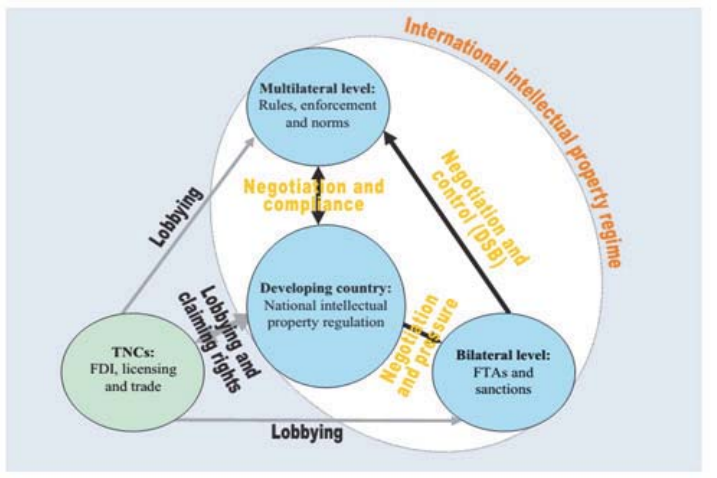

Figure 1: Actors and modes of interaction in the TRIPS Agreement regime (Vogel, 2006, p.64)

As a multilateral agreement within the WTO context, the TRIPS Agreement established a new regime for intellectual property protection.

The TRIPS Agreement represents one part of the trade regime established by WTO. Insufficient intellectual property protection was implicitly redefined as protectionist behavior, therefore conflicting with the free-trade principle of 
GATT/WTO (General Agreement on Trade and Tariffs / World Trade Organization). However, unlike the provisions on tariff and non-tariff barriers, the agreement establishes rules directly governing national regulations on IPRs by specifying the rights, the duration and the standards for enforcement and administration.

The underlying norm is national treatment, which was already included in the WIPO system. Within WTO, its provisions have supranational effect, which means that, by signing and ratifying the agreement, a Member State permits WTO and other members to control its compliance with the TRIPS Agreement and permits the Dispute Settlement Body (DSB) to impose sanctions in cases of non-compliance. (Vogel, 2006)

The emergence of the international intellectual property regime also comprises implications for policymakers in developing countries that go beyond the commitment to implement an international agreement. It means that TransNational Corporations (TNCs), the main actors in the global production network and innovators in the knowledge based economy; generally prefer higher standards of intellectual property protection with regard to the relocation of intellectual property sensitive and technology - intensive parts of production. Shorter product cycles and the growing of investment in Research and Development have increased the willingness of TNCs to reap the rewards for technological advance.

So the internationalization of R\&D has pushed TNCs to relocate part of production that are intellectual property sensitive to developing countries. The TRIPS agreement might have paved the way by ensuring the respective protection standards. (Vogel, 2006)

\subsection{TRIPS and access to medicines}

The ethical problems raised by IPRs are most pertinent when it is socially valuable goods such as life-saving medicines and genetically modified seeds that are given Intellectual Property (IP) protection.

The most controversial issue surrounding TRIPS is its impact on the price and availability of new medicines. If patents are obtained and enforced in developing countries, this could lead to a price control on medicines in these countries. (Eiss, Mahoney \& Satyanarayana, 2007)

Access to health products relies on many factors, including the successful innovation of new technologies. Innovation, in turn, is a complex process, involving many factors (intellectual property is just one) that influence product availability and price.

Research-based pharmaceutical companies invest heavily in the development of new drugs, which is a risky and lengthy process. At the same time, new chemical entities can easily be imitated by competing firms-unless these chemical entities are protected by patent rights. (Fink, 2004)

Apart from the potential effects of patents on post-TRIPS pricing and availability, the comparative therapeutic benefits of new chemical entities over available generics will have health implications. So, in assessing TRIPS over time, the rate of pharmaceutical innovation will be a key variable in measuring the health impact of strengthened patent regimes. (Eiss, et al., 2007)

Crucially, countries have considerable freedom to control the effects of TRIPS on the availability of new health technologies. The countries can do this most effectively by building capacity for IP management and by formulating policies and practices, for courts, patent offices, and other institutions, that favor the poor.

Creatively managed, a global IP regime can be used in the public interest to improve the access of poor populations to new medicines and public health interventions.

Assessing the implications of TRIPS for the development of new products to treat diseases of poverty is difficult. Technology transfer and innovation, in general, are strongly viewed as ways to strengthen an economy; clearly, however, emerging pharmaceutical industries can do more than generate new knowledge, skilled labor, and markets. These industries can address social objectives by developing health-related products to meet local needs.

\section{Concluding Remarks}

- Stronger IPRs will stimulate creative industries in developing countries and promote foreign direct investment, with an overall positive development outcome.

- The degree to which the TRIPS Agreement can be expected to encourage FDI and technology transfer is likely to vary significantly not only between developing countries, but also between sectors, between economic activities and between product types.

- Intellectual property is one of several innovation determinants in health R\&D; when assessing impact, intellectual property must be considered in the context of other competencies. 
- Creatively managed, a global IP regime can be used in the public interest to improve the access of poor populations to new medicines and public health interventions.

- TRIPS enables countries to establish national patent policies and practices that both meet treaty obligations and address national economic needs and social values.

- Countries aspiring to use TRIPS to national advantage must build institutional IP capabilities and policies in order to participate in the global marketplace and benefit from emerging technologies.

\section{References}

Agreement on Trade-Related Aspects of Intellectual Property Rights. (1994). Retrieved from http://www.wipo.int/export/sites /www/treaties/en/agreement/pdf/trips.pdf

Archibugi, D., \& Filippetti, A. (2010). The globalization of intellectual property rights: four learned lessons and four theses, Global Policy 1(2)., pp.146-148. Retrieved from, http://mpra.ub.uni-muenchen.de/21930

Deere, C.( 2009). The implementation game, The TRIPS Agreement and the Global Politics of Intellectual Property Reform in Developing Countries, Oxford University Press Inc., New York.

Dixon, P. \& Greenhalgh, C. A. (2002). The Economics of Intellectual Property: A review to Identify Themes for Future Research, paper for the Intellectual Property Advisory Committee of the UK Patent Office.

Drahos, P.( n.d). Developing Countries and International Intellectual Property Standard - setting. Commission on Intellectual Property Rights. Retrieved from http://www.iprcommission.org/papers/pdfs/study papers/sp8 drahos study.pdf

Eiss, R., Mahoney, RT. \& Satyanarayana, K. (2007). Developing Countries and TRIPS: What Next? In Intellectual Property Management in Health and Agricultural Innovation: A Handbook of Best Practices MIHR: Oxford, U.K., and PIPRA: Davis, U.S.A. Retrieved from www.ipHandbook.org

Fink, C. (2004). Intellectual Property and the WTO. Retrieved from siteresources.worldbank.org

Chang, H.J.(2003). Kicking away the ladder: development strategy in historical perspective, Anthem Press, 8-15.

Kur, A., Levin, M. (2011). Intellectual Property Rights in a Fair World Trade System, Proposals for Reform of TRIPS, Edward Elgar Publishing Ltd, Cheltenham, UK, p. 23.

Matthews, D. (2003), Globalizing Intellectual property Rights: The TRIPs Agreement, Routledge, Taylor and Francis Group, London.

Maskus, K. (2000). Intellectual property rights in the global economy, the Economics of intellectual property rights and globalization, dancing the dual distortion. Washington: Institute for International Economics.

Vogel, C. (2006). The impact and the implications of TRIPs in a Knowledge - based Global Economy: A Developing Country's Perspective, Asia - Pacific Trade and Investment Review, 2(1).

World Trade Organization (2002) 'Basic introduction to the WTO's intellectual property (TRIPS) agreement' Retrieved from http://www.wto.org/english/tratop_e/trips_eltrips_e.htm 
